\title{
A case study of investigation and mitigation measures in a caprock type of landslide in Kyushu Island, Japan
}

Forestry and Forest Products Research Institute/

SUmio MATSUURA

Nagasaki Prefectural Government /

Yoshinori NIIMI

Nagasaki Prefectural Government/

Mitsuru UCHIYAMA
Japan Conservation Engineers /

Koichiro KAWASAKI

Forestry and Forest Products Research Institute /

Shiho ASANO

Forestry and Forest Products Research Institute /

Takashi OKAMOTO

Key words : caprock, immediate measure, control work, restraint work, Hokusho

\section{Introduction}

A large landslide occurred on July 4, 1990 on the slope of Mt. Ishikura, which is located in the northwest of Kyushu Island, Japan (Fig. 1). Although the landslide caused no fatalities or injuries, 126 people from 57 households had to evacuate the district for 9 months, until the end of March 1991.

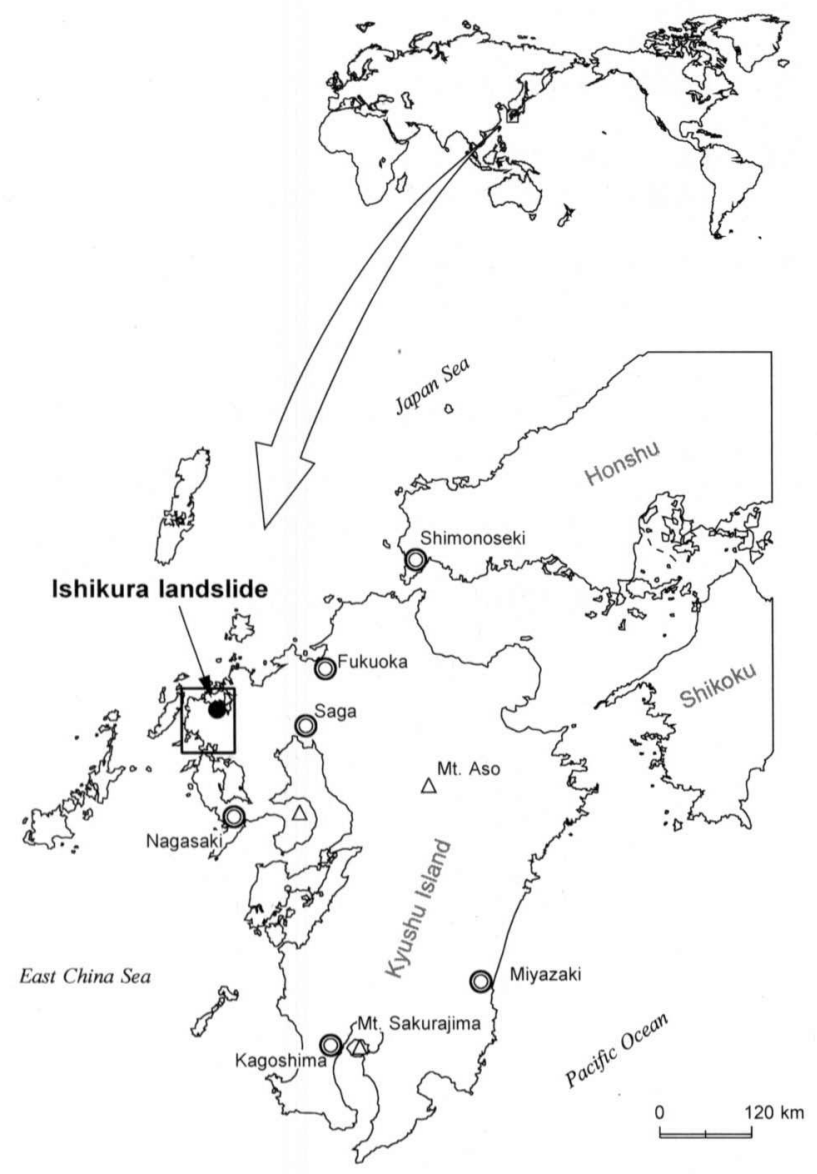

Fig. 1 Location of the Ishikura landslide in Kyushu Island
Preliminary investigations were done first to understand the characteristics and dimensions of the landslide by field reconnaissance and aerial survey. In order to clarify the mechanism by which the landslide was generated and to design appropriate measures against landslides, detailed investigations were conducted by indoor experiments and analyses instead of field investigations such as surveys, observations and tests.

Based on the results of investigation, landslide control works of drainage wells, tunnels and other facilities were constructed. Pile works and anchor works were also designed and implemented to restrain landslides. After completion of these works, the district was transformed into a forest park which is now being effectively used by the local people.

This report describes the series of processes from occurrence of landslide (named "Ishikura landslide") to completion of mitigation and utilization works in a caprock type of landslide of Japan.

\section{Geomorphological and geological backgrounds}

The district extending from the northern part of Nagasaki Prefecture to Saga Prefecture has suffered many large-scale landslides and forms the 'Hokusho' landslide zone (Fig. 2). This zone consists of a thick layer of basalt cap rocks in the Quaternary period with well-developed joints, which unevenly covers a Tertiary formation involving a thin coal layer. Landslides characteristically occur in the basalt layer, the Tertiary formation and the secondary deposit formed by occasional landslides (Oyagi, 1989). This type of landslide is not limited to this district; the landslides 


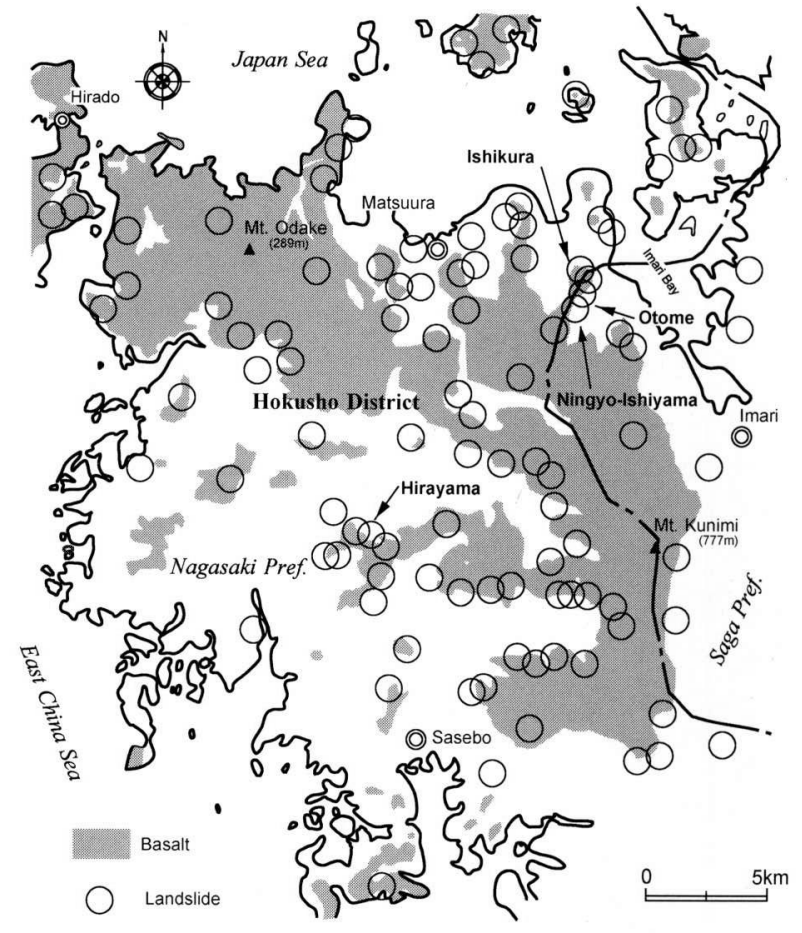

Fig. 2 Geological condition and landslide distribution in Northern Kyushu

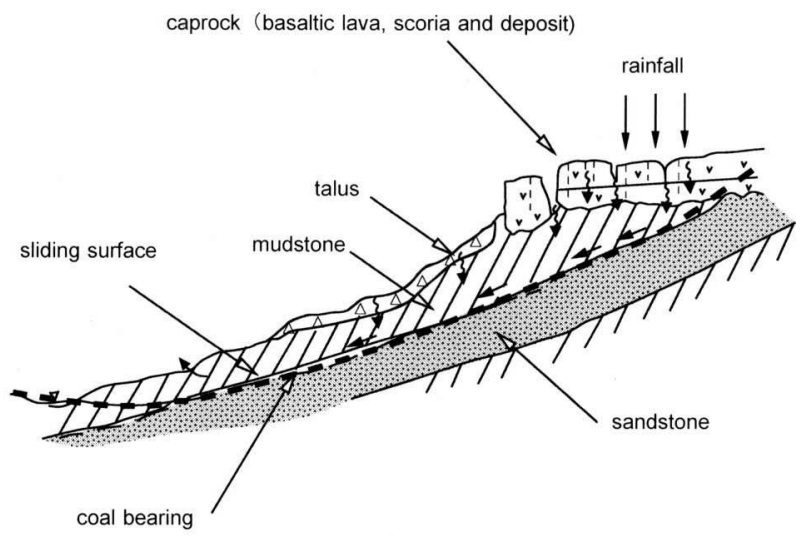

Fig. 3 General mechanism of caprock type of landslide in Kyushu Island

may often occur in areas with the caprock structure (Glawe and Lotter, 1999).

The geology around Mt. Ishikura is also a caprock structure with volcanic rocks called Hokusho basalt covering the sedimentary rocks formed during the Miocene epoch of the Neogene period, which are called the Sasebo and Fukui formations. The Fukui formation is a Tertiary deposit consisting of alternating strata of sandstone and shale, which accumulated during the early Miocene epoch. Basalt exists in various forms, such as fissured lava and porous scoria (Fig. 3).

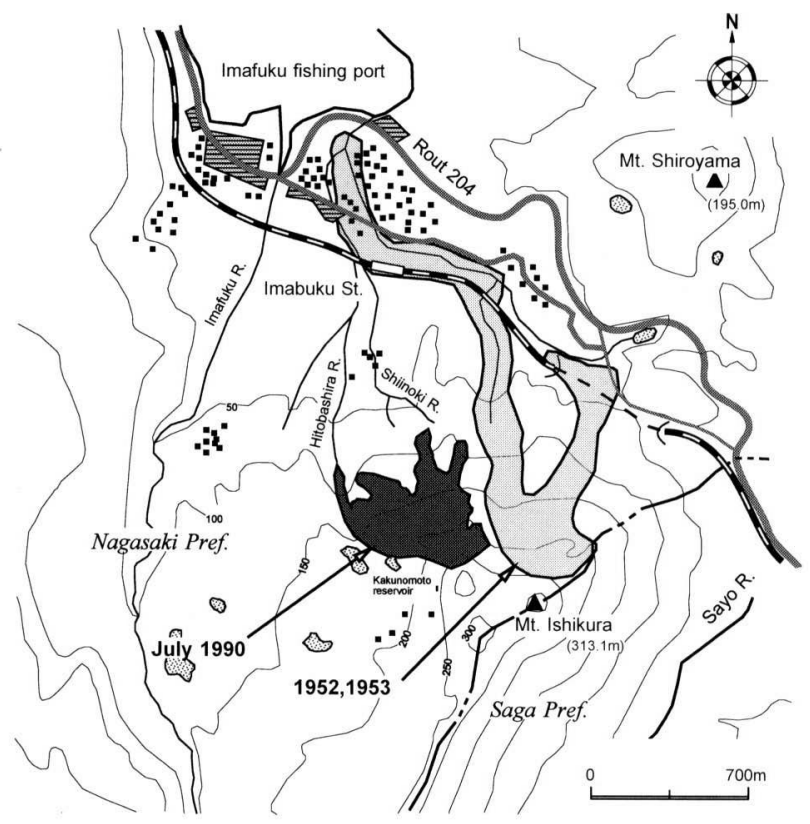

Fig. 4 History of landslides near Mt. Ishikura

\section{Landslide history and catastrophic landslide movement}

\section{1 Landslides around Mt. Ishikura}

Near Mt. Ishikura, a large-scale landslide occurred in 1951 at Otome in Saga Prefecture, and another occurred in 1957 at Ningyo-Ishiyama, both of which caused serious damage to the local residents (Fig.2). Large-scale landslides occurred in 1952 and 1953 on the eastern part of Mt. Ishikura, and fluidized landslide moving masses reached Imafuku Town near the coast and caused serious damage to houses, railways and roads (Fig. 4).

This history of landslides dates back to ancient times. According to the statements of aged persons in the region, there also was a landslide during the latter half of the 1800 s. Radioactive dating with ${ }^{14} \mathrm{C}$ of buried wood that was found during construction of a check dam along the Hitobashira River showed that there had likely been a landslide $16,750 \pm 280$ y.B.P. This district, therefore, has likely suffered many landslides since ancient times.

\section{2 Precursors of the Ishikura landslide}

For ten years until the catastrophic movement in 1990, various events occurred as precursors of a largescale landslide, but all of them were of limited area and scale.

In the summer of 1980, the lower western section of the Ishikura landslide slid during a heavy rainfall. Drainage wells were constructed to control the unstable slope and 82 piles were installed as restraint works in the next year. In 1985, a small-to-medium landslide 
occurred in the eastern section during a torrential downpour. An old scarp near the $260 \mathrm{~m}$ point fell in 1986, and 2 years later, a new open crack near the 290 $m$ was found, extending from the top of the scarp toward the north-east direction.

\section{3 Catastrophic movement on July 4}

In March of 1990, a clear shear plane was observed in a drainage well (Fig. 5), suggesting active and larger landslide movement within the ground. Station markers were installed immediately in March, when abnormalities were observed in drainage wells, and the landslide movement was monitored.

In June, the range that slid on July 4 could be identified even from the ground surface. An automatic monitoring system consisting of four extensometers, four ground displacement gauges, eight water level gauges and one rain gauge was installed and we started to monitor the movements of the landslide on June 25.

The amount of rainfall during the rainy season of this year was $798.5 \mathrm{~mm}$, which was only approximately $20 \%$ larger than that in normal years. However, in one week from June 28 to July 3, continuous rainfall of $386.0 \mathrm{~mm}$ was observed. This heavy torrential rainfall accelerated the catastrophic movement of the Ishikura landslide (Fig. 6).

The extensometer installed at the head scarp (AS-1) recorded an accumulative movement of 4,984 mm from June 26 to 18:00 on July 3. Another movement of $1,872 \mathrm{~mm}$ was observed during the next 3 hours and 40 minutes, till 21:40 of the same day, when the sensor stopped monitoring because the movement exceeded its scale. The landslide movement continued, and the entire slope moved much accompanied by the sound of trees splitting and ground rumbling between 6:00 and 12:00 on the next day.

A scarp of $50 \mathrm{~m}$ height was formed after the catastrophic landslide movement. Moving masses of 3 mil-

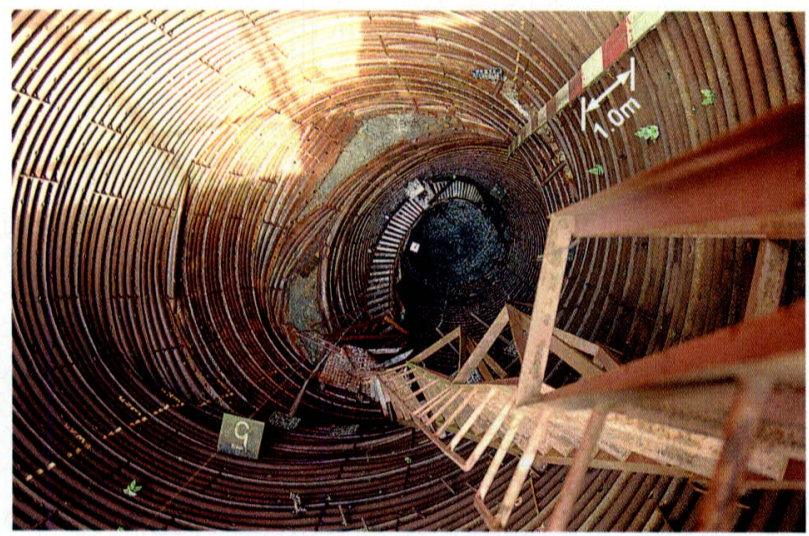

Fig. 5 Sliding surface that appeared in a drainage well lion cubic meters traveled down (Fig. 7) and part of those flowed further down into the Hitobashira and Shiinoki River. The landslide destroyed steel pipe piles, drainage wells, and check dams that had been installed to prevent landslides and caused serious damage to roads, paddy fields, reservoirs, and forests.

\section{4 Fluctuation of groundwater level during land- slide}

Although the catastrophic landslide movement damaged all of the gauges, we had recorded abnormal changes in groundwater level during the landslide. These data showed interactions between groundwater fluctuations and landslide movements, and helped municipal administrators to issue evacuation orders to residents.

Before the landslide, the groundwater level gradually dropped from a high level attributable to previous

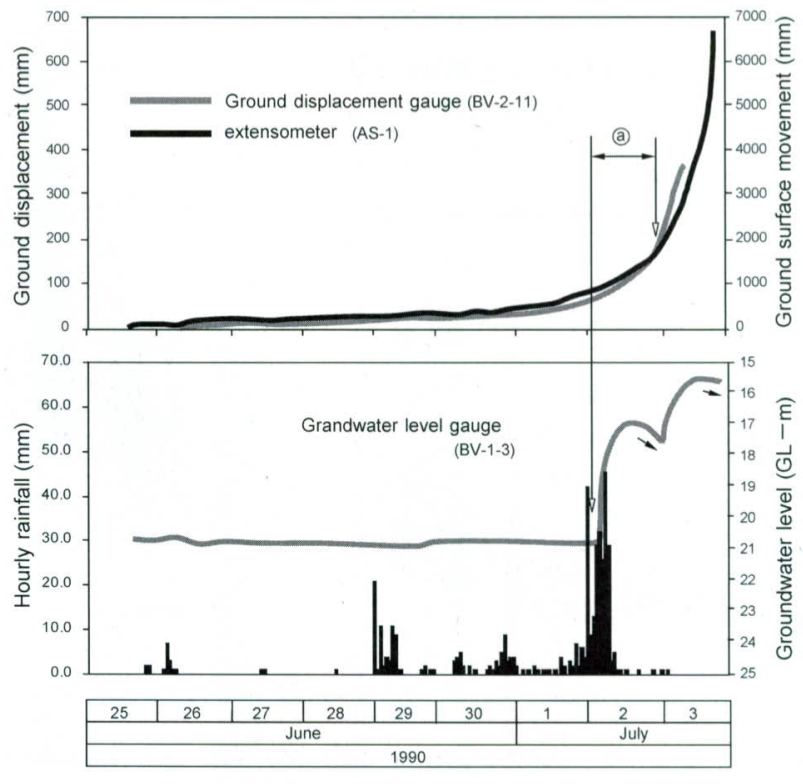

Fig. 6 Landslide movements monitored by automated observation system

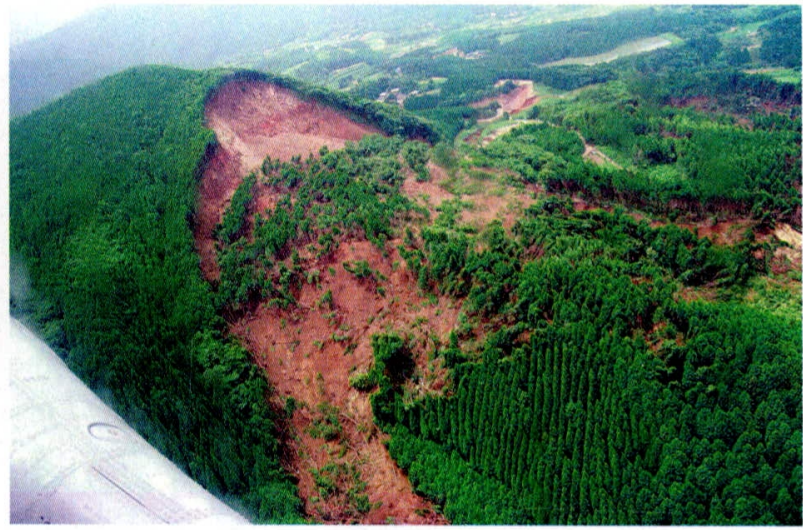

Fig. 7 Overview of the Ishikura landslide immediately after the catastrophic movement 
rainfalls to the normal level on June 28 (Fig. 6). The level rose due to the rain on June 29. A normal rain of about $5 \mathrm{~mm}$ per hour raised the groundwater level by not much more than $30 \mathrm{~cm}$. However, the rain from July 1 till noon on July 2 was $46 \mathrm{~mm}$ in maximum hourly precipitation and $235.4 \mathrm{~mm}$ in total. The first peak of groundwater level appeared six to ten hours later than the peak of the rain. The water level temporarily dropped about $100 \mathrm{~cm}$ but rose again, and showed a peak 20 to 24 hours later, which was $557 \mathrm{~cm}$ higher than the level at 6:00 on June 28.

Landslide movement was rapidly accelerated approximately one day after the start of the water level rise (a) in Fig. 6). On July 3, a movement of $200 \mathrm{~mm}$ was recorded in 12 hours. The water level dropped two times when the landslide mass moved. This phenomenon is likely attributable to the dissipation of ground water through shear surfaces or newly generated cracks in the moving body.

\section{Immediate measures against landslide}

To prevent secondary damage by the landslide movement, the following immediate measures including hard measures (works) and soft measures (warning and evacuation) were taken :

(1) By-pass channels of $1,514.7 \mathrm{~m}$ in total length were constructed to prevent secondary damage by the failure of reservoirs.

(2) The water inside reservoirs, depression cracks, and destroyed drainage wells was drained to prevent water from infiltrating the sliding surface and to prevent the landslide mass from moving again.

(3) Two wire-type sensors were installed to warn residents to quickly evacuate since serious damage was anticipated if the moving mass turned into debris flow.

Immediate measures are taken when the mass is still moving or may move again to minimize or prevent the movement of mass and to prevent secondary damage. This work is therefore very dangerous, and sufficient care must be taken for the safety of workers.

For the Ishikura landslide, quantitative safety standard values were established after the landslide to ensure the safety of workers during immediate mitigation work. The safety standards were based on daily precipitation, and no one was allowed to work on a rainy day with daily precipitation of at least $30 \mathrm{~mm}$ or when the amount of continuous rainfall reached $80 \mathrm{~mm}$. The standard was revised as the mitigation work progressed, so that no person was allowed to work on a rainy day with continuous precipitation of at least 150 $\mathrm{mm}$ or when the continuous rainfall reached $300 \mathrm{~mm}$.

\section{Investigations for mechanism and mitigation measures of landslide}

\section{1 Investigation of geologic structure}

In order to clarify the mechanism of the landslide and to design appropriate mitigation measures, the geological structure, sliding surface and condition of groundwater were investigated by exploration boring, field observation and tests.

Analyses on the mechanism of landslide and our monitoring before catastrophic movement showed that three blocks constitute the Ishikura landslide (Blocks I,

Table 1 Dimensions and conditions of each block

\begin{tabular}{|c|c|c|c|c|}
\hline \multicolumn{2}{|c|}{ Dimensions } & I & II & III \\
\hline \multicolumn{2}{|c|}{ Direction of movement } & NW & NNW & NNW \\
\hline \multirow{3}{*}{ 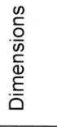 } & Area $\left(\mathrm{m}^{2}\right)$ & 105,800 & 113,200 & 7,300 \\
\hline & Length (m) & 350 & 450 & 90 \\
\hline & Width (m) & 350 & 350 & 80 \\
\hline \multirow{3}{*}{ 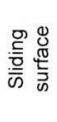 } & Depth (m) & $20-35$ & $20-35$ & 25 \\
\hline & Shape & Plane & Plane & Unknown \\
\hline & Dip $\left(^{\circ}\right)$ & $2.5-6.0$ & $2.5-6.0$ & 11.5 \\
\hline \multirow{2}{*}{ 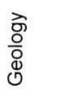 } & Moving body & $\begin{array}{l}\text { Sandy deposit } \\
\text { with basalt }\end{array}$ & $\begin{array}{l}\text { Sandy deposit } \\
\text { with basalt }\end{array}$ & $\begin{array}{l}\text { Sandy deposit } \\
\text { domain }\end{array}$ \\
\hline & Stationary layer & $\begin{array}{l}\text { Sandy shale } \\
\text { (sh-2) }\end{array}$ & $\begin{array}{c}\text { Sandy shale } \\
(\mathrm{sh}-2)\end{array}$ & $\begin{array}{l}\text { Sandy shale } \\
\text { (sh-1) }\end{array}$ \\
\hline \multirow{2}{*}{ 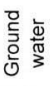 } & Classification & $\begin{array}{l}\text { Unconfined } \\
\text { groundwater }\end{array}$ & $\begin{array}{l}\text { Unconfined } \\
\text { groundwater }\end{array}$ & $\begin{array}{l}\text { Unconfined } \\
\text { groundwater }\end{array}$ \\
\hline & Pressure head $(m)$ & $2.0-10.0$ & $2.0-9.0$ & 2.0 \\
\hline
\end{tabular}
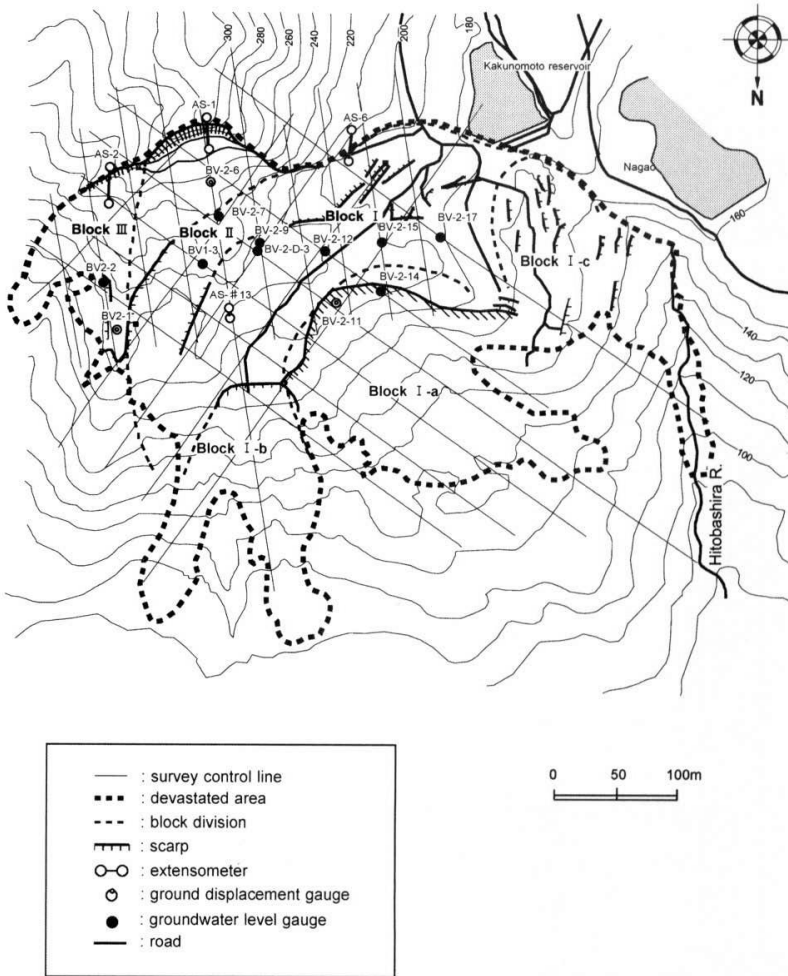

Fig. 8 Block division of Ishikura landslide 
II, and III) (Table 1). We also found that there are three sub-blocks (I-a, I-b, and I-c) as secondary sliding masses at the bottom end and the right side of Block I (Fig. 8).

Exploration boring showed that the ground section above the sandy shale (sh-2) layer was a highly disturbed mixture of clay and gravel. In some parts, the ground below the sandy shale layer was also disturbed gravel and clay, but in most parts was hard, from which we could take core samples. Pipe strain gauges and ground displacement gauges installed within the blocks provided data that support our hypothesis that the disturbed sandy layer which contained basalt slid over the upper surface of the sandy shale layer (sh-2).

\section{2 Evaluation of sliding surface}

The depth of the sliding surface estimated by the analyses and the depth determined during the construction of drainage wells are listed (Table 2). The ta-

Table 2 Estimated elevation of sliding surface and actual elevation confirmed by drainage well works

\begin{tabular}{|c|c|c|c|c|c|c|}
\hline $\begin{array}{l}\text { Drainage } \\
\text { well No. }\end{array}$ & Elevation & $\begin{array}{l}\text { Excavation } \\
\text { depth }\end{array}$ & $\begin{array}{l}\text { Depth of } \\
\text { sliding } \\
\text { surface }\end{array}$ & $\begin{array}{c}\text { El. of sliding } \\
\text { surface } \\
\text { (actual) } \\
\text { A }\end{array}$ & $\begin{array}{c}\text { El. of sliding } \\
\text { surface } \\
\text { (estimated) } \\
\text { B }\end{array}$ & $A-B$ \\
\hline 1 & 195.60 & 20.80 & 17.30 & 178.30 & 178.30 & 0.00 \\
\hline 2 & 188.00 & 17.30 & 12.30 & 175.70 & 175.80 & -0.10 \\
\hline 3 & 208.39 & 41.80 & 35.75 & 172.64 & 172.20 & 0.44 \\
\hline 4 & 200.00 & 36.80 & 32.50 & 167.50 & 166.50 & 1.00 \\
\hline 5 & 181.49 & 20.30 & 15.75 & 165.74 & 166.50 & -0.76 \\
\hline 6 & 179.50 & 19.30 & 15.15 & 164.35 & 164.20 & 0.15 \\
\hline 7 & 174.70 & 19.80 & 16.20 & 158.50 & 158.30 & 0.20 \\
\hline 8 & 167.00 & 16.80 & 13.10 & 153.90 & 155.70 & -1.80 \\
\hline 9 & 180.00 & 14.80 & 10.20 & 169.80 & 168.80 & 1.00 \\
\hline 10 & 189.80 & 27.80 & 24.00 & 165.80 & 166.80 & -1.00 \\
\hline 11 & 194.45 & 34.80 & 31.20 & 163.25 & 162.40 & 0.85 \\
\hline 12 & 187.70 & 33.80 & 29.20 & 158.50 & 158.40 & 0.10 \\
\hline
\end{tabular}

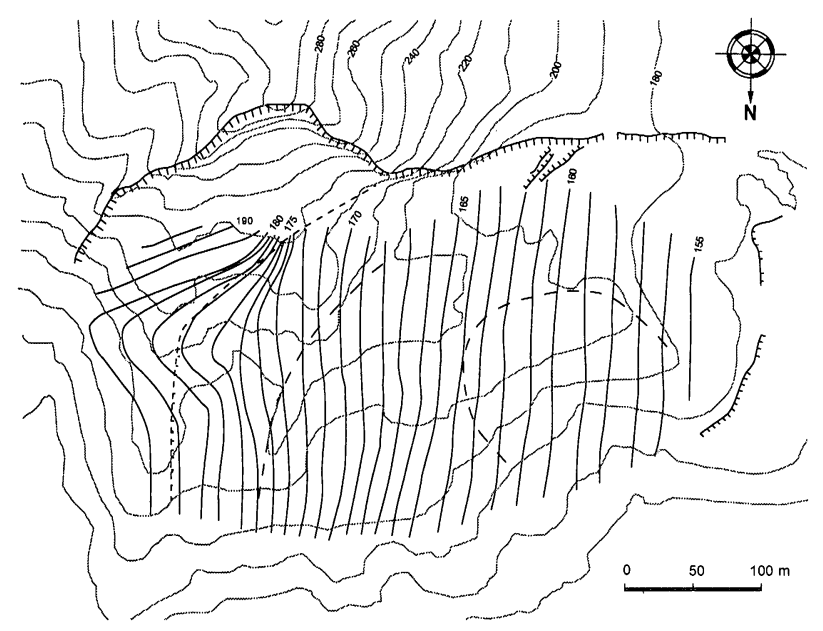

Fig. 9 Relationship between contour lines of sliding surface and ground surface ble shows that the analyses could estimate the depth within an error of approximately $1.0 \mathrm{~m}$. A contour map of the sliding surface was created based on the depth measured during exploration boring and drainage well construction (Fig. 9). The map shows that the sliding surface was inclined toward the west. However, the landslide mass traveled along the inclination of the slope (toward the northwest or north-northwest). Therefore, the main vector of the landslide was different diagonally from the direction of maximum dip of the sliding surface; this might be due to the resistance of the peripheral geomorphology.

\section{3 Groundwater investigation}

Groundwater logging showed that the sandy shale layer was impermeable and acted as the confining bed since a larger flux of high water pressure slightly above the sliding surface was observed in most boreholes (Fig. 10). The water head was especially high at the top and left side of Block I. There was a narrow strip zone of high water pressure, which formed a depressed zone. In this zone, high-pressure heads exceeding $10 \mathrm{~m}$ of piezometric elevation were observed. Therefore, groundwater in the depression zone was closely related to the generation of the landslide. A

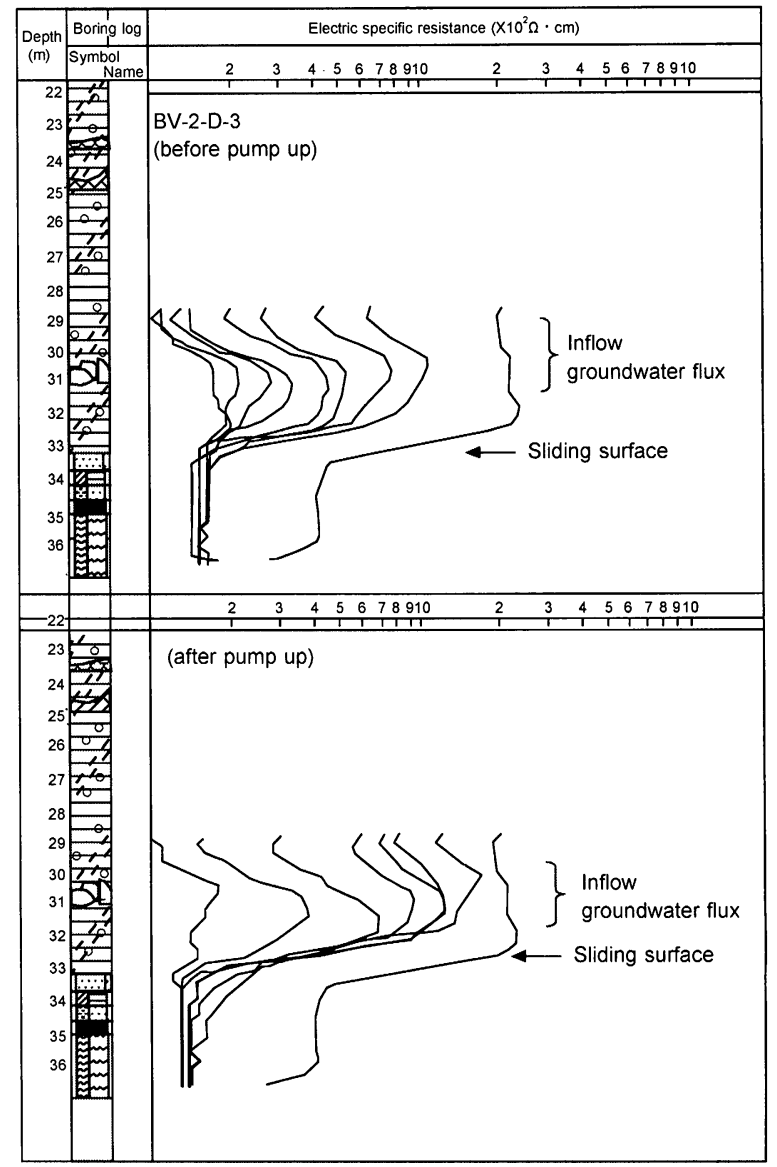

Fig. 10 Results of groundwater logging tests 
drawdown test conducted at a drainage well in the depressed zone showed a high permeability coefficient of $k=3.2 \times 10^{-3} \mathrm{~cm} / \mathrm{sec}$ and it also showed that the radius of the affected area was $110 \mathrm{~m}$.

Our surveys revealed the condition and characteristics of both sliding surface and groundwater. The main vector of a landslide may differ from the inclination of the sliding surface and provide valuable data for predicting the direction of a landslide, estimating the distance that the moving body may reach, and designing control and restraint works, such as the location and penetration depth for installing steel piles. The high water pressure in the depression zone may be attributable to geo-hydrological structures which caused the landslide and was created by landslide movement.

\section{Permanent mitigation works based on compre- hensive analyses}

\section{1 Concept of mitigation works}

In this landslide, a rise in groundwater pressure caused a notable drop in safety factor. Since rainwater may have infiltrated deep into the ground during heavy rain, the rise in pore pressure at the sliding surface could have caused another landslide. Therefore, three-dimensional drainage works that combine drainage wells and tunnels within the bed rock were likely to be the most effective.

At the same time, a large quantity of moving mass remained at the head of the landslide, and was destabilizing the slope. The landslide mass therefore had to be removed to ensure safety during the construction and to maximize the effects of the drainage works ( $F u$ nato and Shinagawa, 1985). Earth removal work was the highest priority since it improves the safety against landslide as the work progresses (Okubo and Asai, 1985).
After drafting a rough plan, basic methods of undertaking mitigation work were examined based on the analyses of the generation mechanisms for each block (Fig. 11).

\section{2 Stability analyses of blocks}

A clear depressed zone was formed at the top of Block I as a result of the landslide movement. Since there was a narrow caved-in strip at the top of the block before the landslide, this block should have a constantly reactivated history. The stability of the block was calculated with the SHIN-Janbu method (Shin, 1989). The SHIN-Janbu method is useful for analyzing the stability of rockslide and is based on the Simple Janbu method. The SHIN-Janbu method calculates stability from 1) the pressure of groundwater existing within cracks at the upper part of the sliding area as a landslide external force acting on a wall of a moving body and 2) the uplift pressure acting on the sliding surface extending downward.

To calculate the amount of mitigation work needed, the stability of each block was calculated as described above. To minimize analytical errors in the stability analyses, the Lambe-Whitman approximate threedimensional analysis method was used, which determines the two-dimensional safety factors of various sections consisting of the main and sub-traverse lines and assumes the mean of the sections, which is determined based on their cross section areas, as an approximate three-dimensional safety factor (Lambe and Whitman, 1969).

\section{3 Investigation of parameters for stability analy-} ses :

Stability analyses were conducted first by using a safety factor of $F_{C W L}=1.00\left(F_{C W L}\right.$ : Safety factor at critical water level) and $c^{\prime}=0.0 \mathrm{kPa}$, and $\phi^{\prime}=10.65^{\circ}$ was derived by back calculating these values. Since this

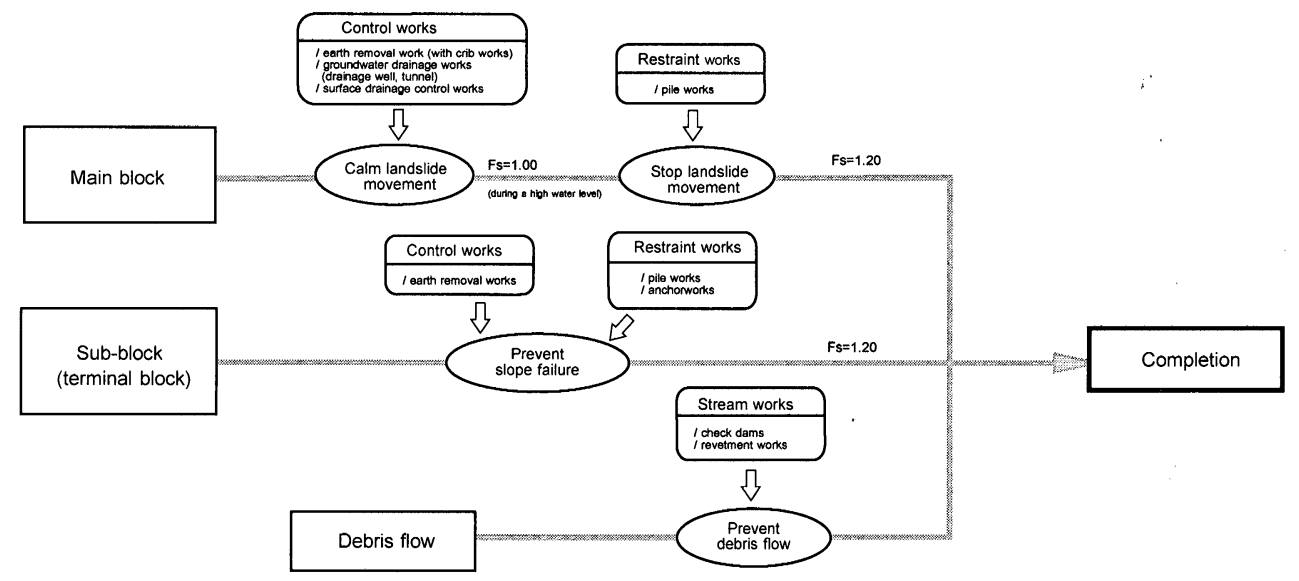

Fig. 11 Concept of landslide mitigation works on each block 


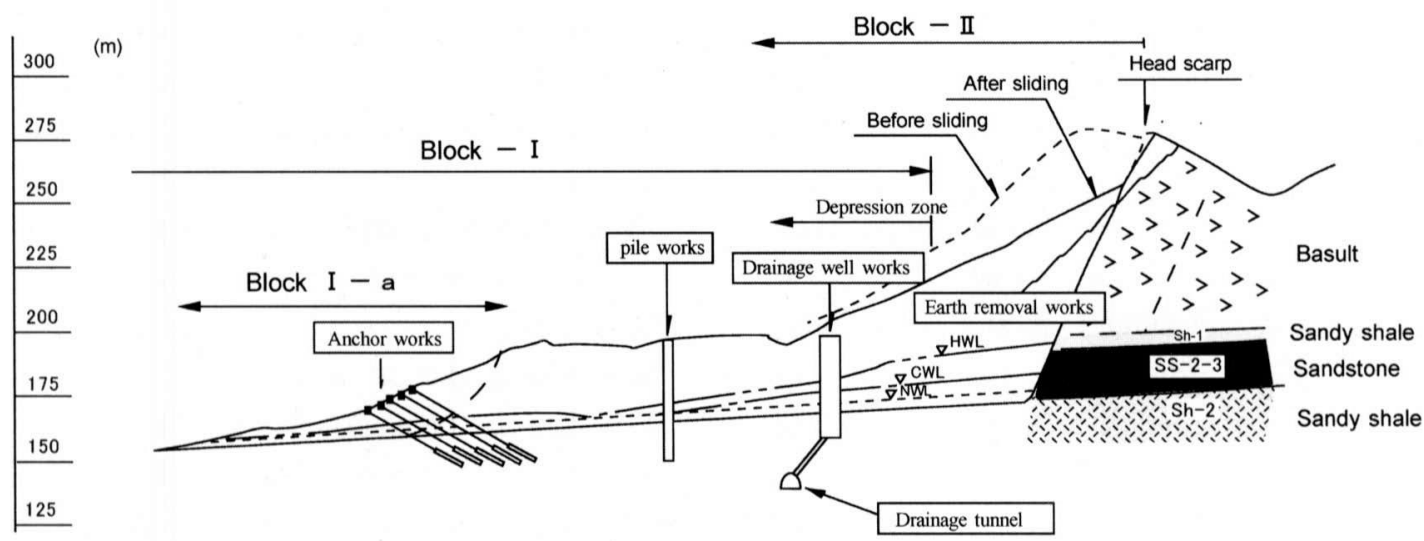

Fig. 12 Geological structure of each section and location of mitigation works

Table 3 Results of ring shear tests

\begin{tabular}{ccc}
\hline \hline $\begin{array}{c}\text { Drainage well } \\
\text { No. }\end{array}$ & $\begin{array}{c}\text { Depth of sliding } \\
\text { surface } \\
(\mathrm{GL}-\mathrm{m})\end{array}$ & $\begin{array}{c}\text { Residual strength } \\
\left(\phi \mathrm{r}^{\prime}\right)\end{array}$ \\
\hline \hline No.3 & 35.75 & 11.25 \\
No.5 & 15.75 & 7.95 \\
No.12 & 29.20 & 11.67 \\
\hline \hline average & & 10.29 \\
\hline \hline
\end{tabular}

landslide traveled a long distance, the value of $c$ seemed to drop around zero as the residual strength. Therefore, we adopted the value of $c=0$ (Skempton, 1964).

Specimens were sampled from the sliding surface found in three drainage wells under construction, and a ring shear test was conducted with the clayey specimens (Lupini et al., 1981). The mean of the test results from which abnormal values had been excluded was $\phi_{r}^{\prime}$ $=10.29^{\circ}$ (Table 3$)$. On the other hand, $\phi^{\prime}=10.65^{\circ}$ was derived for Block I at the water level and under the slightly moving state before the landslide by giving a safety factor $F s=1.00$ and cohesion $c^{\prime}=0.0 \mathrm{kPa}$ and back calculating these values. Although the value determined by ring shear tests was slightly smaller (Chandler, 1983), the $\phi$ values were similar, showing that our estimation of sliding surface and critical water level was adequate.

The $\phi^{\prime}$ derived from back calculation should be the mean of $\phi$ for the entire sliding surface when these results and their relationship with the stability analyses of blocks are considered. Therefore, the $\phi$ for the entire sliding surface was estimated to be $\phi^{\prime}=10.65$ determined by the back calculation method.
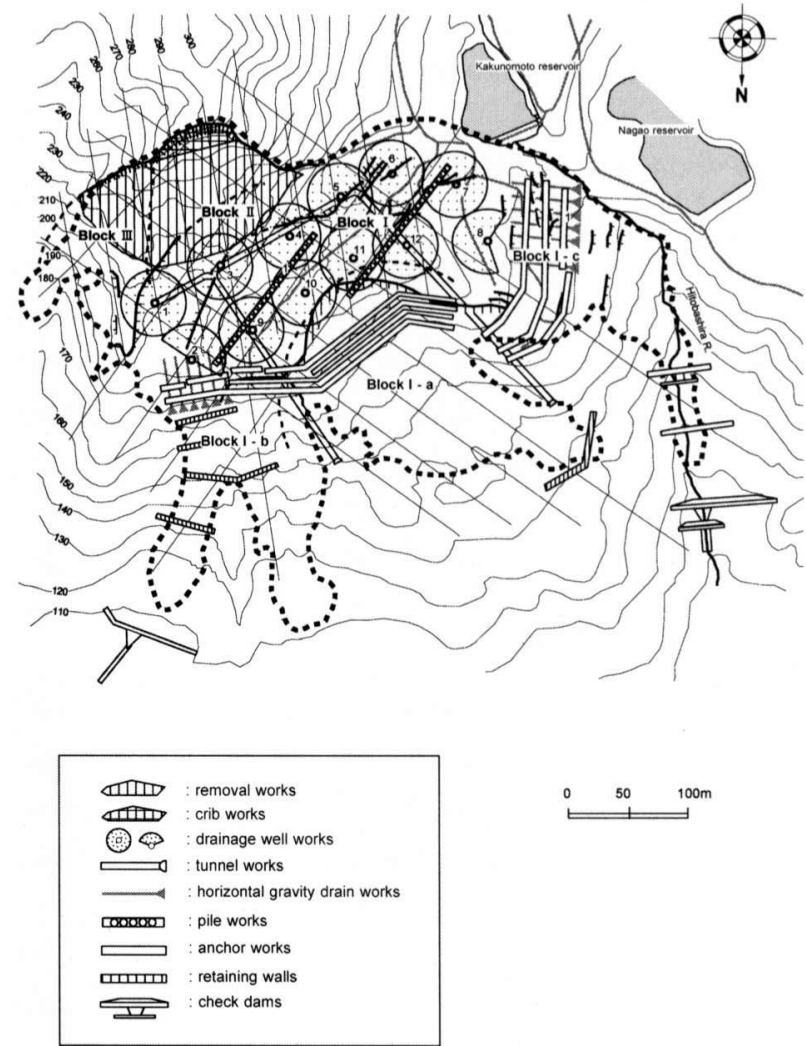

Fig. 13 The plan layout for landslide mitigation works

\section{4 Planning mitigation works in detail based on stability analyses}

To plan the concrete landslide mitigation works, we used parameters of $c^{\prime}=0.0 \mathrm{kPa}$ and $\phi^{\prime}=10.65^{\circ}$ which were back-calculated by the water-level at the time the landslide occured. Considering the groundwater conditions, various landslide mitigation works were designed to achieve the target safety factor of each block (Fig. 12).

Blocks I and II: For Blocks I and II, which form the principal part of the landslide, the unstable moving mass at their crest had to be removed to enhance the safety of the slope. Twelve drainage wells were to be 
installed most effectively at approximately $60 \mathrm{~m}$ intervals within the depressed zone at the block heads (Fig. 13). Groundwater was to be discharged from the wells through tunnels that were to be constructed within the stable rock formation. To drain the groundwater effectively, drainage borings were dug all around the wells. These works, however, can only handle $F s=1.00$ during an anticipated critical high water level, and it was difficult to obtain the required safety factor. Therefore, restraint works were to be used to provide the necessary safety factor of 1.20.

Blocks I-a to I-c: Since the groundwater level was low in these blocks, drainage works alone cannot ensure the necessary safety. Therefore, earth removal and anchor works were needed to stabilize the unstable masses.

\section{Landslide mitigation measures}

\section{1 Warning and evacuation system}

An automatic monitoring system developed by combining new sensors was installed to replace the sensors destroyed by the landslide, to ensure the safety of workers during the construction of landslide control and restraint works and to evaluate their effects, such as earth removal and drainage wells.

The system consisted of sensors for monitoring the precipitation, groundwater level, landslide movement and debris flow, and devices that recorded all of the data from the sensors. Devices were switching units, data loggers and a single computer which controlled interval time, data storage, preliminary analysis and data communication.

When a landslide movement was detected, the data were to be forwarded to the Committee for Investigating Measures against Landslides and other related sections of the Nagasaki Prefectural Government through the head office established in the North Nagasaki Promotion Bureau of the Nagasaki Prefectural Government in Sasebo. The data were also transmitted to fire stations, police offices and local people through the head office installed by Matsuura-City Hall (Fig. 14).

\section{2 Landslide control works}

\subsection{Earth removal work}

As a result of the initial stability analysis, an enormous quantity of earth had to be removed, and it was necessary to find a place to deposit it. With the cooperation of the municipal government of Matsuura City, the earth was used for reclaiming land in Imafuku Fishery Port, on which a fish processing facility will be built. Stability analyses were conducted for each construction step, the plan was further investigated, and the amount of earth was $247,000 \mathrm{~m}^{3}$ in the final plan. The earth was removed from the landslide section with backhoes and was transported by dump trucks. After the removal works, concrete crib works were constructed at the headscarp of the landslide.

\subsection{Drainage tunnels}

Tunnels were built by assembling liner plates. This method was appropriate for the ground and groundwater conditions at the site, and is safe since the tunnels are left bare only for short periods of time. Liner plates were horseshoe type and $2.5 \mathrm{~m}$ high. The tunnels were excavated using dynamite. The debris was loaded on locomotives with rocker shovels and removed from the tunnels. Battery-type locomotives were used due to the size of the tunnels and to prevent air pollution inside.

\subsubsection{Drainage wells}

Eleven drainage wells were built by assembling liner plates. The wells were $3.5 \mathrm{~m}$ in diameter, and the liner plates were 3.2 to $6.0 \mathrm{~mm}$ thick, which were the values determined from the earth pressure at rest. After

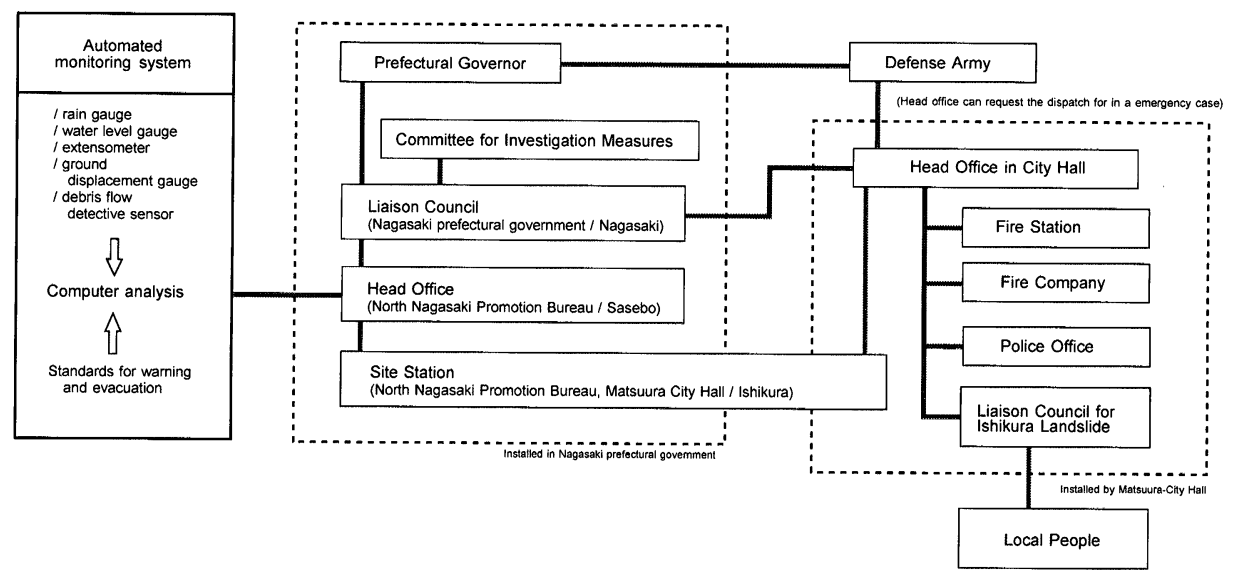

Fig. 14 Flow of data for warning and evacuation acquired by the automatic monitoring system 


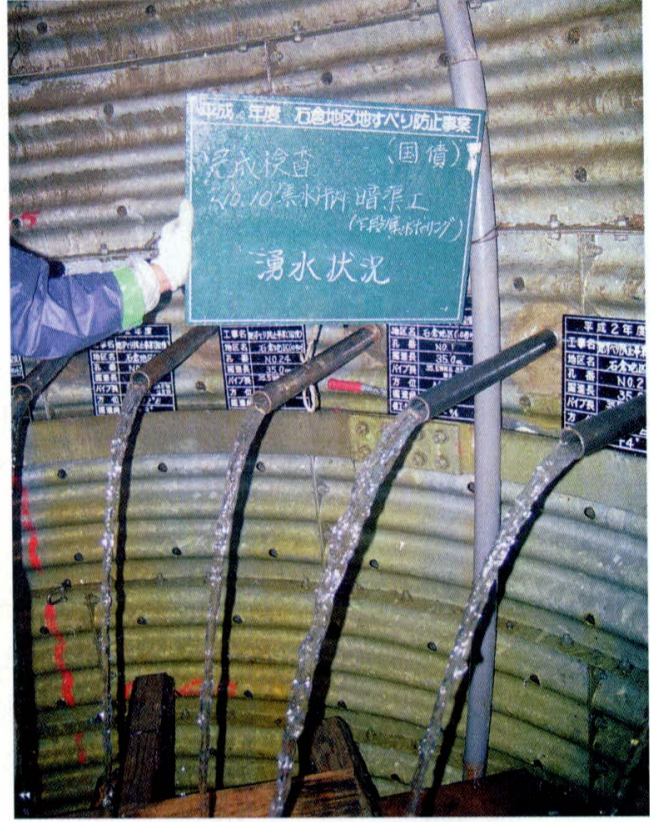

Fig. 15 Water discharging from drainage bores

the excavation of the wells, drainage borings were installed from each well in all directions (Fig. 15). We built 487 drainage borings of $12,015 \mathrm{~m}$ in total length. The groundwater collected by the drainage well was discharged to the water channel through the drainage tunnel.

\section{3 Landslide restraint works}

\subsubsection{Anchor works}

Anchors should be installed along the direction of landslide movement with sufficient consideration of other mitigation works, the horizontal and inclination angles of the anchors, and the range to install them, since the effect of an anchor varies with inclination angle. Intervals and steps of anchor installation should be comprehensively investigated, and the most economical anchor positions must be determined.

In the Ishikura landslide, anchors were installed to provide a safety factor of 1.20 against landslides at Blocks I-a, I-b and I-c. Since progressive failure of Tertiary formations was anticipated, expanding and bearing type anchors, rather than friction-type anchors, were used. The anchors were installed at $2.0-\mathrm{m}$ intervals in four steps with design pulling strength of $560 \mathrm{kN} /$ anchor. Approximately 50\% of the design load was applied as the pretension. We installed 855 anchors in total.

\subsection{Pile works}

Steel piles were installed in Blocks I and II to attain the target safety factor of 1.20 . The pipes were installed perpendicularly to the direction of the landslide movement. Seventy-six steel pipes $(d=800, t=40 \mathrm{~mm})$

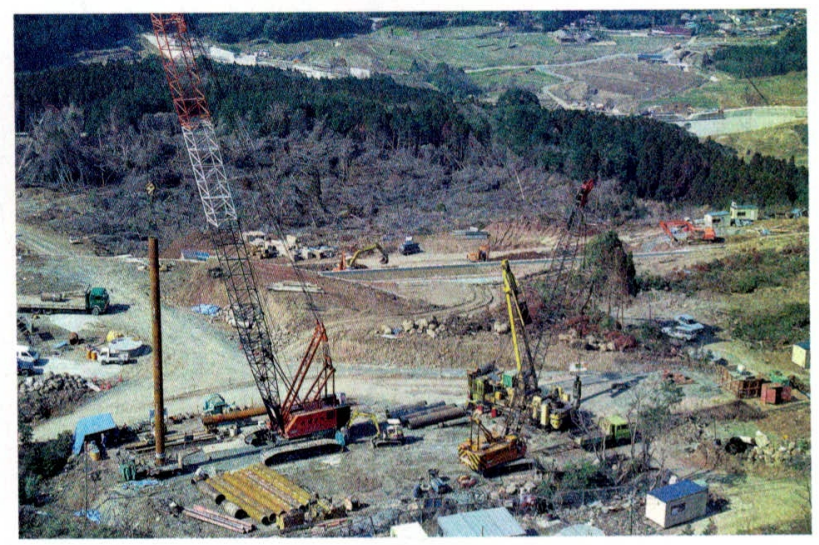

Fig. 16 Building large-diameter steel pipe piles using a crawler crane

were installed at $4.50-\mathrm{m}$ intervals with a penetration depth of $6.10 \mathrm{~m}$ below the sliding surface. We used centrifugal pipes which are thicker and more resistant to shearing and bending, and so could reduce the number of piles and thus the cost.

The pits for installing the steel piles were excavated with the all-casing method. This method excavates a hole with a hammer grab by protecting the hole with casing, and inserts a pile with a crawler crane (Fig. 16). A hammer grab is a bucket type excavator that drops a heavy bucket for several meters to excavate a hole. With this method, excavation was conducted efficiently and quickly.

Welding was fully automated since the pipes were thick. Ultrasonic tests that were based on JIS standards were conducted to check that the pipes were appropriately welded. Electric welding during rain may cause strain and insufficient strength since the rain cools the welded surface too quickly, and the rain may also cause short circuits. Therefore, we avoided working during rain as much as possible, and when unavoidable, covered the welding surfaces with plastic sheets.

\section{Multipurpose utilization of the landslide}

The Ishikura landslide was stabilized by performing various control and restraint works under strict safety control (Fig. 17).

A meeting was then held to discuss effective utilization of the area and the construction of Ishikura Forest Park. Based on the results of the meeting, the five-year Living Environment Forest Construction Project started in 1994.

The forest park has two objectives : 1) educational and 2) recreational. This landslide area was treated with immediate measures and most of the principal 


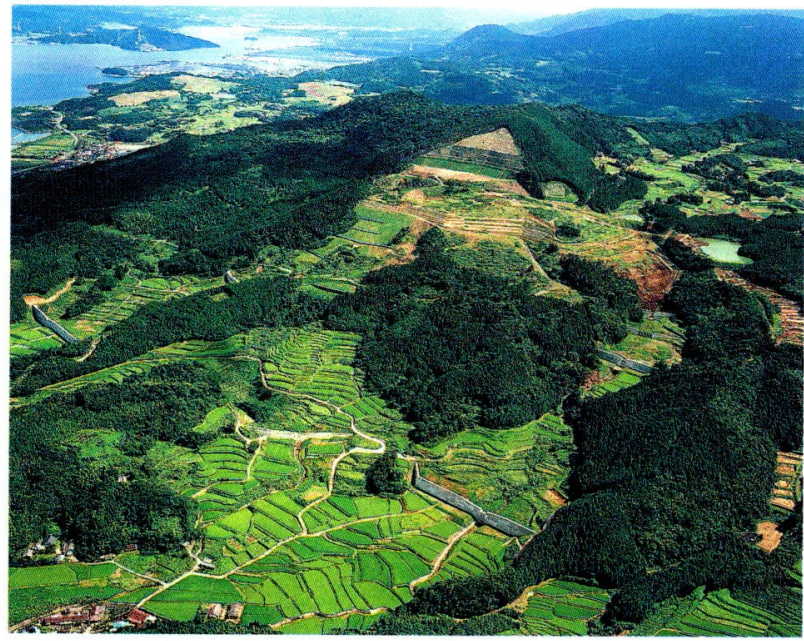

Fig. 17 Plane view of Ishikura landslide in 1994 (Imari Bay and Imari City in the distance)

landslide control and restraint works. People can see these works, which are mostly unfamiliar to them, and learn about the hazards of landslides. The landslide area was transformed into a forest park by planting various tree species and now provides a relaxing space for users.

\section{Summary}

On July 4, 1990, a large-scale caprock type of landslide occurred on the northwest slope of Mt. Ishikura in Kyushu Island of Japan. This landslide was $500 \mathrm{~m}$ long, $350 \mathrm{~m}$ wide and 20 to $35 \mathrm{~m}$ deep with 3 million cubic meters of moving body.

Since signs of landslide activities such as deformation of drainage wells had been observed from March of the same year, landslides were closely watched by using an automatic monitoring system. As a result, an evacuation order was issued and the catastrophic movement caused no human injury. The acquired data, which showed interactions between groundwater fluctuations and landslide movements, were also helpful for understanding the mechanism of the landslide.

In order to clarify the mechanism of the landslide and to design appropriate measures, detailed investigations were conducted by comprehensive analyses instead of indoor experiments and field investigations. These investigations revealed not only the geological structure and condition of the groundwater but also the inclination and strength of the sliding surface.

Landslide mitigation measures, which were mainly control works with restraint works, were designed based on the results of investigations. To reduce the landslide driving force and to maximize the effect of drainage works, earth removal work was executed. Other control works that combined drainage well and tunnels were constructed to drain the large amount of groundwater in the deep part of the ground. Thick steel piles of large diameter were installed to stop the landslide movement and to attain the target safety factor as a restraint work. Anchor works were also adopted to prevent landslides in three sub-blocks.

After completion of mitigation works, the landslide area was converted into a forest park, where people can relax and learn about natural disasters.

\section{References}

Chandler, R. J. (1983) : Recent European experience of landslides in over consolidated clays and soft rocks, Proc. of the 4 th International Symposium on Landslide, Toronto, pp. $61-81$.

Funato, K. and Shinagawa, M.(1985) : The forestry conservation and erosion control by the Forestry Agency, Japan, Proc. of the IVth International Conference and Field Workshop on Landslides, The Japan Landslide Society, Tokyo, pp. 99-106.

Glawe, U. and Lotter, M.(1999) : Rock slope behavior prior to failure at the Tressdorfer Hoehe, Austria, Sassa, K. ed., Landslides of the world, Kyoto Univ. Press, Kyoto, pp. $103-$ 108.

Lambe, T.W. and Whitman, R.V.(1979) : Soil mechanics, John Wiley \& Sons, New York, 553pp.

Lupini, J. F., Skinner, A. E. and Vaughan, P. R.(1981) : The drained residual strength of cohesive soils, Geotechnique, 31 (2), pp. $181-213$.

Okubo, S. and Asai, Y. (1985) : "Hard" and "Soft" measures taken by the Ministry of Construction, Japan to prevent slope failure disasters, Proc. of the IVth International Conference and Field Workshop on Landslides, The Japan Landslide Society, Tokyo, pp. $123-130$.

Oyagi, N.(1989) : Geological and economic extent of landslides in Japan and Korea, Brabb \& Harrod (eds), Landslides: Extent and Economic Significance, Balkema, Rotterdam, pp. $289-$ 302.

Shin, J.(1989) : Stability analysis by SHIN-Janbu method, Shin, J. ed., Jisuberi Kogaku (Landslide Engineering), Sankaido, Tokyo, pp. 664-666. (in Japanese)

Skempton, A. W.(1964) : Long-term stability of clay slopes, Geotechnique, $14(2)$, pp. $77-101$.

(Received June 10, 2004, Accepted October 20, 2004) 